\title{
Analysis of Village Extension Workers' Capabilities in Producing Electronic Media for Extension Education in Imo State, Nigeria
}

\author{
${ }^{1}$ Emerhirhi E., F.N. Nnadi ${ }^{2}$ and E.O. Okoroma ${ }^{2}$
}

${ }^{I}$ Department of Agricultural Education, Federal College of Education (Technical), Omoku Rivers State, Nigeria.

${ }^{2}$ Department of Agricultural Extension, Federal University of Technology, P.M.B. 1526, Owerri, Nigeria.

\author{
Received: 30 Sept. 2020 / Accepted 15 Nov. 2020 / Publication date: 25 Nov. 2020
}

\begin{abstract}
The dearth of Village Extension Workers (VEWs) who have requisite skills and competencies in the production of electronic media for extension education in the study area has remained the bane of effective extension education, particularly to rural clientele who are constrained by literacy to communicate. Hence, the study analyzed the capabilities of Village Extension Workers' to produce electronic media for extension education in Imo State. Specifically, the study examined the level to which VEWs are trained in electronic media production; assessed the capabilities of the VEWs to produce electronic media; as well as assessed the relationship between the training given to VEWs and the capabilities of VEWs to produce electronic media. Data were collected from 120 sampled extension personnel using structured questionnaire. Data analysis was done using mean, standard deviation and Z-test. The results show that electronic media production skills taught in extension were inadequate as only 4 out of the 16 requisite skills areas understudied were taught to VEWs. The result also revealed that the average extension worker lacked the capability $(\bar{X}=0.6)$ to produce electronic media. At $5 \%$ Significantg level, the result showed that the training given to the VEWs on electronic production did not differ with the capabilities of the VEWs to produce electronic media (Z-cal =1.93; Z-tab =1.96). The study concluded that VEWs in the study area lacked the capabilities to produce electronic media for extension education, and therefore recommended a review of extension pre-service and in-service training curriculum towards making it more robust and effective in equipping VEWs with the knowledge and skills needed to leverage the media for effective extension education.
\end{abstract}

Keywords: VEWs, training needs, electronic media production, extension service delivery, communication, ICTs.

\section{Introduction}

Sustainable agricultural development is a vision that implies mobilizing small scale farmers who produce bulk of the food for greater productivity and livelihood. The success of this largely depends on the active role of agricultural extension, since access to extension services enhances farmers' productivity and earnings from agriculture (Akinbile and Ndaghu, 2005). The activities of extension are inclined to keep the farmers better informed as well as improve their analytical capability and communication as to help them in their decision making related to farming (Asiabaka, 2002 and Nwachukwu, 2013). To meet this demand, extension ensures that innovation flows from the producers to consumers and from facilitators to users of agricultural information, technologies and knowledge.

According to Banmeke and Balogun (2011) with adequate design and deployment of Information Communication Technologies (ICTs) extension can perform its communication role more efficiently, as the revolution in ICTs have continued to collapse the earlier barriers of agricultural information dissemination. At the center of this attainment are devices and channels with electrical, audio and visual capabilities, such as the computer multimedia, television, radio, video, internet feeds/online content, teletext, videotext, audio tapes, audio books, films, interactive video, teleconferencing, Extension training therefore seeks to develop the competencies of the extension worker to meet the challenges of making and incorporating the media in extension work (Asiabaka, 2012).

Village Extension Workers (VEWs) are extension personnel resident in rural milieu who are deployed to assist rural clientele identify and solve their technology needs, information needs, home 
economic needs, postharvest needs, marketing needs, credit needs by teaching them improved methods, techniques and innovations for greater productivity. However, Tladi (2004) noted that training given to VEWs have not been because the trainings are usually done for the wrong reasons; the training contents are not related to the jobs of extension workers, and the development and design of the programmes are usually not based on any specific needs. Thus, notwithstanding that electronic media have long been deployed in extension service delivery, requisite technical knowledge, skills, abilities and attitude for the production of these electronic media are highly deficient among extension personnel in the study area as evident in the nonexistence of functional electronic media production unit across extension agencies as well as the dearth of empirical evidence suggesting otherwise. Omotayo (2011), identified limited access to current readable database on agricultural information and a monopolistic situation that makes agricultural research information service centres the custodian of CD-ROM database, multimedia knowledge base, in-house database, regional database, national and in-house publications, among the unfortunate conditions resulting from the performance deficiencies of State-wide extension organizations. This study therefore sought to investigate if VEWs are capable of producing electronic media for extension education. Specifically, the study sought to:

i. Examine the level to which electronic media production skills are taught in extension training;

ii. Assess the capabilities of VEWs to produce electronic media;

iii. Analyze the relationship between the capabilities of the VEWs and their perceived training needs

\section{Methodology}

The study was carried out in Imo State of Nigeria. Imo State is located in the South Eastern zone of Nigeria and lies between latitudes $4^{0} 45^{\prime} \mathrm{N}$ and $7^{0} 15^{\prime} \mathrm{N}$ and longitude $6^{0} 50^{\prime} \mathrm{E}$ with land area of $5,530 \mathrm{Km}^{2}$. It is bordered by Abia State on the East, by River Niger and Delta State on the West, by Anambra State to the North and Rivers State to the South (Wikipedia, undated). It has an estimated population of about 4.8 million people and an annual growth rate of 3.35 percent (NPC, 2010). Extension services are undertaken by Imo State Agricultural Development Programme (ADP) with its tentacles spread across the three zonal structure of Owerri, Orlu and Okigwe demarcated into 39 blocks and 326 circles for effective extension activity (Imo ADP, 2002).

The population of the study consisted of all extension personnel of Imo ADP. Random sampling procedure was used to select 40 extension workers from each of the three zones of Imo State to give a total sample size of $120 \mathrm{VEWs}$ for the study. The level of electronic media production skills taught in extension training was measured on 4-point Likert type scale of Very Adequate Taught $=4$, Highly Taught $=3$, Lowly Taught $=2$, Not Taught $=1$. The mean of the responses was obtained by adding the values of the scale and dividing by the number of scales to derive the discriminating index. The electronic media production capability of the VEWs was determined using an 8-point capability assessment index of measured as dummy: Yes $=1$, No $=0$. The discriminating index was set at an average mean score of $\bar{X} \geq 1.5$ for being capable and $\bar{X}<1.5$ for not being capable. Data were collected using structured questionnaire and analyzed using mean score, standard deviation and Z-test.

\section{Result and Discussion}

\section{Training given to VEWs on Electronic media production}

Table 1 result revealed that electronic media production skills taught in extension were inadequate as only 4 out of the 16 requisite skills areas understudied were perceived taught in extension training. These included script writing $(\bar{X}=2.5)$ and electronic reporting $(\bar{X}=3.0)$. Subject areas not taught included: video recording and production $(\bar{X}=1.0)$, audio recording and production $(\bar{X}=1.1)$, Digital photographical production $(\bar{X}=1.4)$, computer multi-media production $(\bar{X}=1.5)$, internet feeding/streaming $(\bar{X}=2.0)$, video editing $(\bar{X}=2.0)$, photo-texting $(\bar{X}=2.0)$, voicing/commentary $(\bar{X}=3.2)$, phone-based electronic media production $(\bar{X}=2.4)$, web-based electronic media production $(\bar{X}=1.2)$, elearning material production $(\bar{X}=1.1)$ and audio book production $(\bar{X}=1.4)$. The average standard deviation of $(\mathrm{SD}=0.4)$ shows that the VEWs were homogenous in their perceived assessment of the electronic media skills taught in extension training. This result highlights the poor attention given to electronic media production in extension curriculum in the study area. The danger this portends 
according to Arokoyo (2011), is that those being trained for extension job may not have the technical capabilities to be productive in the emerging e-agricultural work environment. Such as, in deploying cyber extension, CD/DVD readable database, farmer helpline services, e-clientele, e-interaction, creation and maintenance of location specific electronic database, tele-education for farmers, etc.

Table 1: Distribution of VEWs according to training on electronic media production

\begin{tabular}{llccc}
\hline Electronic media production skills & Mean score & SD & Remark \\
\hline 1. & Video recording and production & 1.0 & 0.2 & NAT \\
2. Digital photo graphical production & 1.4 & 0.2 & NAT \\
3. Computer multi-media production & 1.5 & 0.3 & NAT \\
4. Audio recording and production & 1.1 & 0.5 & NAT \\
5. Internet feeding /streaming & 2.0 & 0.2 & NAT \\
6. Non-linear video editing & 1.2 & 0.2 & NAT \\
7. Video effects /Animation & 1.7 & 0.6 & NAT \\
8. Graphics designing & 2.0 & 0.4 & NAT \\
9. Script writing & 2.5 & 0.6 & AT \\
10. Voicing/commentary & 1.1 & 0.4 & NAT \\
11. Photo-texting & 2.0 & 0.3 & NAT \\
12. Phone based electronic media production & 2.4 & 0.4 & NAT \\
13. Web-based electronic media production & 1.2 & 0.5 & NAT \\
14. e-learning material production & 1.1 & 0.2 & NAT \\
15. Audio-book production & 1.4 & 0.2 & NAT \\
16. Electronic reporting & 3.0 & 0.9 & AT \\
17. Average assessment & $\mathbf{1 . 9}$ & $\mathbf{0 . 4}$ & NAT \\
\hline
\end{tabular}

Source: Field Survey Data, $2018 \quad \bar{X}>2.5$ (NAT) $\bar{X}<2.5$ (AT)

VAT $=$ Very Adequate Taught, $\mathbf{H T}=$ Highly Taught, $\mathbf{L T}=$ Lowly Taught, $\mathbf{N T}=$ Not Taught

\section{Electronic media production capabilities of VEWs}

Table 2 is an 8-point electronic media production index designed to assess the technical abilities of VEWs in making electronic media contents, devices and channels for extension work. Using an average mean score of $\bar{X}=1.5$ the result shows that the average extension worker lacks the capability $(\bar{X}=0.6)$ to produce electronic media (record and produce videos, create computer multimedia files, produce online media contents; make graphic design; undertake digital photo creation; create e-learning materials, etc). This finding explains the inability of extension agencies in the study area and Nigeria in general to maintain a functional electronic media unit, even where such unit exists, its functionality is rarely at optimum.

Corroborating this result, Okon (2013) in his finding observed lack of electronic media like DVD/CD-ROM libraries of agricultural programmes, making it difficult for channels such as the broadcast media to be more responsive to farmer's information needs. In the ensuing incapability to package their own messages, extension organizations continue to patronize mainstream media professionals who often lack formal background in agriculture or development for their demonstration videos, audio recordings, online contents, graphic works, digital photo creation, etc. Pur and Gwary (2008) noted that the resulting documentary (message) could be technically distorted by the media producer or presenter to suit their sense of appeal rather than the information needs of the target audience. However, the result also reveals that the VEWs were adjudged capable of carrying out ereporting (cartoon illustration, photo news, teleconferencing, skype reporting, script writing, news network). The implications of the finding are expressed in the apprehension and consciousness raised by some studies, such as the work by Umunakwe et al. (2015) which see the growing internet subscription of farmers and expanding media platforms such as the social media, video sites, websites, voice sites, etc, as a source of concern for extension practitioners. This is so given that the advancement in ICTs and the liberalized information sharing internet platform continue to bring VEWs face to face with the threat of losing their statutory role of innovation dissemination to noncommissioned media practitioners, especially on the internet. 
Table 2: Distribution of VEWs by electronic media production capability

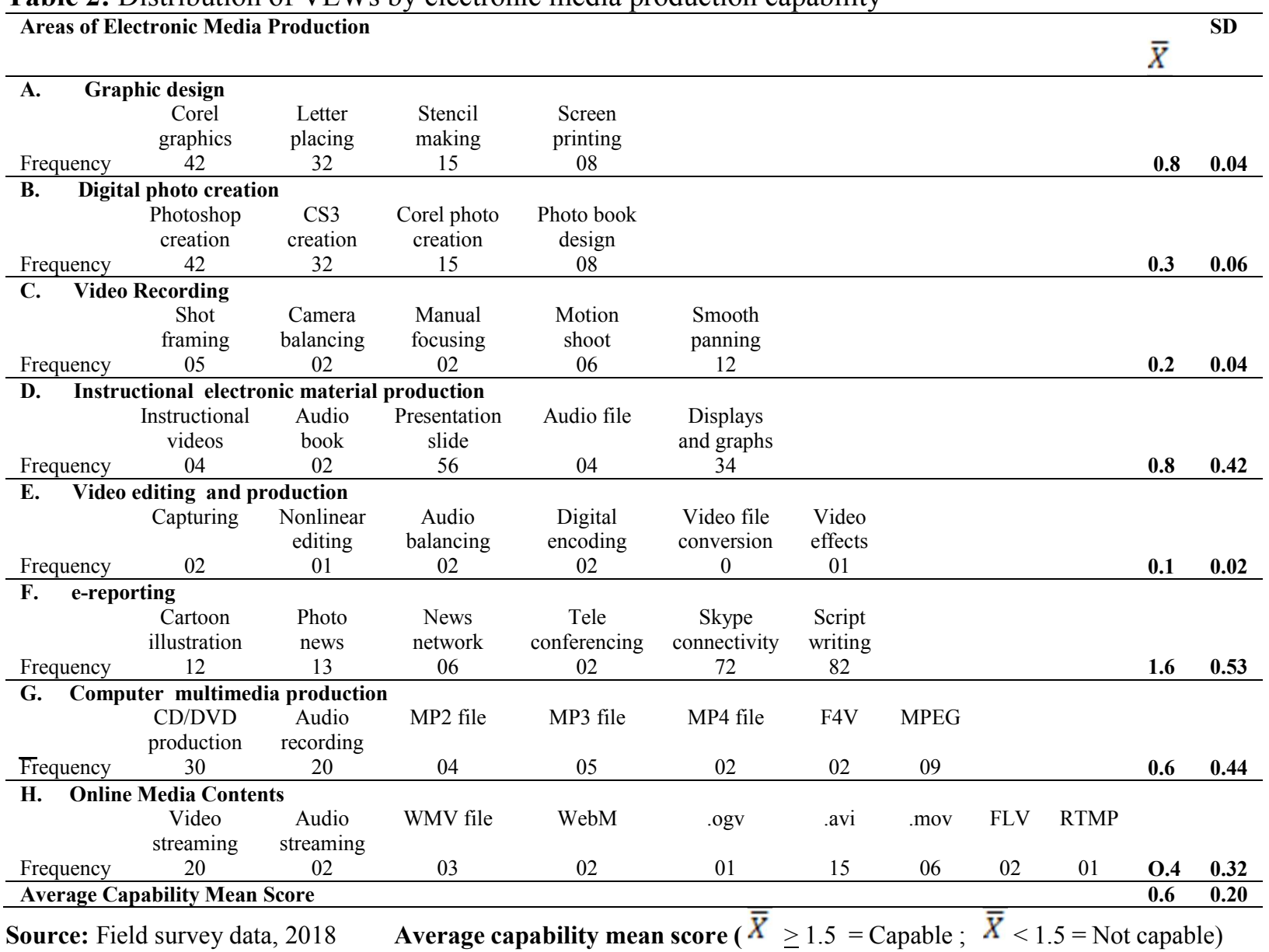

\section{Training and Capability Differential of VEWs}

Table 3 shows the Z-test of significant difference between the training given to VEWs and the capabilities of VEWs to produce electronic media gave $(X=30.556$; $S . D=7.002)$ and $X=31.685$; $S . D=8.172$ ), respectively. The test produced a $Z$-value of 1.93 which was not significant when compared with the critical Z-value of 1.96 at 5\% probability level for a two tailed test. Hence, the null hypothesis which states that there is no significant difference between training given to VEWs and capabilities of the VEWs to produce electronic media was accepted. It could be inferred from the result that the capabilities of the VEWs in making electronic media are strongly related with their training needs, as one could trigger the other or be the result of the other. Improving the capabilities of the VEWs for greater productivity therefore implies addressing their training needs

Table 3: Z-test of significant difference between the capabilities of the VEWs to produce electronic media and their perceived training needs

\begin{tabular}{lcccccl}
\hline Variables & $\mathbf{N}$ & Mean & $\begin{array}{c}\text { Standard } \\
\text { deviation }\end{array}$ & Z-cal. & Z-tab & Decision \\
\hline $\begin{array}{l}\text { Training given to } \\
\text { VEWs }\end{array}$ & 120 & 30.556 & 7.002 & 1.93 & 1.96 & $\begin{array}{l}\text { The null hypothesis } \\
\text { is accepted }\end{array}$ \\
$\begin{array}{l}\text { Production } \\
\text { capabilities }\end{array}$ & 120 & 31.685 & 8.172 & & & \\
\hline
\end{tabular}

Source: Field survey data, 2015

\section{Conclusion and Recommendation}

The revolution in ICTs, especially, the electronic media is liberalizing information dissemination, such that farmers now depend on the media for their information needs. At the same time, the possibility of spreading distorted technical agricultural information on the media is increasingly becoming. Hence, 
for the extension service to maintain control of the quality of agricultural information distributed on the media, its extension personnel must develop the capability to produce and package their own message in an electronic media format.

\section{References}

Akinbile, L.A. and A.A. Ndaghu, 2005. Access to extension and poverty alleviation strategies of farm families in Adamawa State, Nigeria. Journal of Agricultural Extension. 8:1-6.

Arokoyo, T. (2011). ICTs application in agricultural extension service delivery. In; Madukwe, M.C.(Ed.). Agricultural extension in Nigeria. A publication of Agricultural Extension Society of Nigeria (AESON), Ilorin

Asiabaka, C.C. (2002). Agricultural extension: A hand book for practitioners. Port Harcourt: Molsyfm United Services.

Banmeke, T.O. and E.O. Balogun, 2011. Deploying e-Agriculture for Information Delivery to Farmers in Attaining the Millennium Development Goals in Nigeria. Proceedings of the $16^{\text {th }}$ of the Annual NationalConference. AESON $21-24^{\text {th }}$ March, 2011.

National Population Commission (NPC), 2010. Population distribution by sex, states, LGAs and senatorial districts, 2006 population and housing census, priority tables vol III, NPC, Abuja, Nigeria. Retrieved 10/10/2013 from www.population. Gov.ng/2006/national and state population and housing/ htm

Nwachukwu, I., 2013. Agricultural extension. In; Nwachukwu, I. (Ed.) Agricultural extension and rural development. Umuahia: Lamb House Publishers.

Okon, D.P., 2013. Information and Communication Technologies use in extension. In: Nwachukwu, I. (Ed.) Agricultural extension and rural development. Umuahia: Lamb House Publication.

Omotayo, O. (2011). ICT and agricultural extension: emerging issues in transforming agricultural technology in developing countries. In; Nwachukwu, I. (Ed.) Agricultural Extension in Nigeria. Ilorin: Agricultural Extension Society of Nigeria (AESON).

Pur, J. T. and M.M. Gwary, 2008. Determinants of effectiveness of electronic media in agricultural information delivery in Yola North Local Government Area of Adamawa State, Nigeria. PAT 2008; 4 (1): 21-27: ISSN: 0794-5213. Retrieved 23/5/2014 from www. patnsuk journal. com/ currentissue

Tladi, F.M., 2004. Job content and training needs of agricultural extension agents in South-Central Botswana1. Journal of International Agricultural and Extension Education doi: 10.5191/jiaee.2004.11304.

Umunakwe, P.C, R.N. Nwakwasi, A.O. Ani, E.N. Ejiogu-Okere and F.N. Nnadi, 2015.Constraints to the adoption of improved cassava varieties among rural farmers in Imo State, Nigeria. Asian Journal of Agricultural Extension, Economics \& Sociology. 6(1): 56-63, 